Jurnal Sosial Bisnis Peternakan: Vol. 1, No. 1 November 2019 | Hal. 19

\title{
DAMPAK EKSKLUSI SOSIAL DAN MODEL PEMBERDAYAAN PETERNAK
}

\section{The Impact of Social Exclusion and The Farmer Empowerment Model}

\author{
M. Munandar Sulaeman ${ }^{1}$, Ali Mauludin ${ }^{2}$, Marina Sulistyati ${ }^{3}$, Lilis Nurlina ${ }^{4}$, Unang Yunasaf ${ }^{5}$, \\ dan Syahrul Alim ${ }^{6}$ \\ ${ }^{1,2,3,4,5,6}$ Staff Pengajar Fakultas Peternakan Universitas Padjadjaran \\ Email:mdr_sul@yahoo.com
}

\begin{abstract}
ABSTRAK
Eksklusi sosial dan model pemberdayaan peternak merupakan kajian sosiologis pembebasan peternak dari dominasi pemodal besar atau kapitalis. Peternakan khususnya peternak rakyat (unggas) dewasa ini telah mengalami tantangan dan hambatan dalam keberlanjutan usahanya. Hal ini terkait baik suprastruktur dan Infrastruktur pengembangan peternakan yang tidak memihak kepada peternak rakyat. Tujuan dari kajian ini adalah untuk mengetahui akar masalah penyebab terjadinya eksklusi sosial peternakan rakyat dan dampaknya serta model pemberdayaan bagaimana yang dapat mengatasi marjinalisasi peternak. Studi ini dilakukan dengan metode campuran atau (mix method) meliputi studi kasus, studi dokumentasi dan kajian fenomenologis. Hasil penelitian menunjukkan bahwa akar masalah terjadinya marjinalisasi peternak disebabkan oleh adanya regulasi atau aturan yang menyebabkan pihak pemodal melakukan intervensi usaha yang menguasai seluruh sumber modal usaha mulai dari hulu sampai hilir. Solusi pemberdayaan yang relatif mampu mengatasi permasalahan adalah pemberdayaan rekonstruksi komprehensif yang terkait perubahan regulasi dan dan adanya konvensi dalam aspek penyediaan sapronak dan harga produksi.
\end{abstract}

Kata Kunci: Eksklusi sosial; pemberdayaan , rekonstruksi komprehensif

\begin{abstract}
Social exclusion and farmer empowerment models are sociological studies of Breeder's liberation from major financiers or capitalist domination. Farms in particular the people's Farmers (poultry) now have experienced challenges and obstacles in their sustainability efforts. It is related to both the superstructure and infrastructure development of farms that are not favoring to people's farmers. The objective of this study is to know the root cause of social exclusion of people's farms and its impact as well as the empowerment model of how that can overcome the marginalization of breeders. The study was done by mixed method or (mix method) including case studies, documentation studies and phenomenological studies. The results showed that the root cause of the problem of the marginalization the breeder is caused by regulation or rule that causes the financier to intervene business intervention that control the entire source of business capital ranging from upstream to downstream. An empowerment solution that is relatively capable of addressing the problem is a comprehensive reconstruction empowerment related to regulatory changes and the existence of conventions in the aspect of providing Sapronak (production means) and production price.
\end{abstract}

Keywords: social exclusion; Empowerment, Comprehensive reconstruction 


\section{A. PENDAHULUAN}

Program SDGs tentang produksi dan konsumsi (pangan) yang bertanggungjawab menuntut bidang peternakan untuk meningkatkan laju produksi dan daya konsumsi protein hewani bagi masyarakat. Data sampai saat ini menunjukkan masih adanya gap konsumsi protein hewani harapan 150 gram/kapita /hari sedangkan pencapaian baru 47,80 gr/ $/ \mathrm{h}$. Demikian juga konsumsi daging per tahun masih jauh dari harapan, konsumsi daging sapi baru 1,8 $\mathrm{kg} ; 7 \mathrm{~kg}$ daging ayam dan $0,4 \mathrm{~kg}$ daging kambing (OECD, 1918), sehingga daging masih impor.

Sistem mandiri adalah sistem usaha peternakan ayam broiler dengan modal sepenuhnya ditanggung peternak. Peternak menyediakan kandang, peralatan, tenaga kerja, dan sarana produksi ternak (DOC, pakan, serta OVK/obat, vitamin, dan vaksin) serta memasarkan sendiri ternaknya, baik ternak hidup maupun dalam bentuk karkas (daging). Kondisi peternak mandiri saat ini menurun drastis. Menurunnya jumlah peternak mandiri menunjukkan hilangnya kondusivitas ranah usaha yang menunjang peternak rakyat, karena sarana produksi peternakan ketergantungan pihak lain akibat lemahnya modal dan lemahnya akses peternak terhadap sumberdaya peternakan. Kelemahan semacam ini terkait dengan adanya eksklusi sosial.

Pada saat yang sama kondisi peternakan sedang menghadapi kondisi anomali akibat eksklusi sosial. Eksklusi sosial diartikan sebagai adanya kebijakan sengaja atau tidak sengaja berupa tindakan baik dari pemerintah maupun agen lainnya yang mengeksklusi sekelompok orang dari sebuah kesempatan,sehingga terputusnya akses dari sebuah kesempatan. Dalam hal ini peternakan sebagai korban eksklusi menjadi terpuruk di segala lini. Eksklusi sosial diartikan sebagai proses multidimensi dengan berbagai bentuknya : yang menutup partisipasi dalam membuat keputusan, proses politik, akses untuk sumber atau kesempatan kerja dan sumber daya material (ekonomi) dan integrasi terhadap proses kultural wajar (Byrne,1999). Eksklusi sosial merupakan proses dinamis yang menutup keluar, sebagian atau sepenuhnya dari aspek sosial ekonomi, politik atau sistem kultural yang menentukan integrasi sosial personal dalam masyarakat (Munandar dan Rochadi, 2018)

Dampak eksklusi sosial melalui kebijakan regulasi tatakelola usaha peternakan baik rakyat maupun perusahaan besar, secara faktual telah mematikan usaha peternakan rakyat mandiri. Upaya penanggulangan permasalahan ini dilakukan dengan pemberdayaan yang meliputi penguatan dari segi zooteknik dan segi posisi tawar dalam menghadapi regulasi eksklusi sosial.

\section{B. MATERI DAN METODE}

Metode penelitian campuran (mix method) meliputi studi kasus, yaitu meneliti tentang, studi dokumentasi dan kajian fenomenologis. Pendekatan fenomenologi dilakukan dengan memahami data tentang permasalahn peternakan dari berbagai sumber informasi media sosial, kemudian menguji isi/konten, menemukan tematema, melakukan maping kronologis pemikiran, mengkaji kasus lain, dan menemukan pola dari kasus. (Smith, 2009:79-107). Studi kasus dilakukan di Jawa Barat. Pola Kemitraan Unggas Jawa Barat, yaitu mengkaji proses dan aspirasi peternak, analisis dilakukan dengan tahap reduksi data, display data dan penarikan kesimpulan.

\section{HASIL DAN PEMBAHASAN}

\section{a. Akar masalah Eksklusi Sosial \\ 1. Masalah Regulasi dan Eksklusi Sosial}

Eksklusi sosial menurut Sen (2000:15) diartikan dengan dua kategorikan, yaitu Eksklusi Aktif dan Eksklusi Pasif. Eksklusi aktif adalah adanya kebijakan atau tindakan baik dari pemerintah maupun agen lainnya yang dengan sengaja mengeksklusi sekelompok orang dari sebuah kesempatan, Sedangkan Eksklusi pasif 
yaitu terputusnya akses dari sebuah kesempatan tanpa disengaja, misalnya Undang-Undang peternakan, yang dapat membatasi sebagian peternak dalam mendapatkan sumber daya atau kesempatan untuk memenuhi kebutuhannya sebagai peternak.Konsep eksklusi sosial digunakan karena kaitan luas meliputi aspek sosial, ekonomi dan politik, dengan fokus utama devripasi atau pencabutan hak.

Ciri eksklusif sosial adalah multidimensional, dinamis, relatif hubungan yang retak, adanya hambatan akses ke sumberdaya komunal dan adanya pembatasan partisipasi dan kelembagaan (Todman,2004). Berbagai regulasi sebagai eksklusi sosial yang menghambat pembangunan peternakan tampak berikut :

Pertama, Undang-Undang Nomor 18 Tahun 2009 tentang Peternakan dan Kesehatan Hewan, yang memvalidasi adanya usaha integrasi pada peternakan unggas. Dampak ketentuan tersebut praktik yang bersifat monopolistik dan kartelisasi dalam setiap komoditas penting produksi perunggasan lebih bebas dan marak ${ }^{1}$ Dampaknya usaha budidaya peternakan rakyat (mandiri) banyak yang bangkrut dan usahanya mati.

Tidak ada kontrol terhadap perusahaan terintegrasi besar yang memiliki usaha dari hulu sampai hilir, yang bertemu di pasar tradisional dengan hasil produksi budidaya peternak mandiri.Perusahaan terintegrasi usahanya meliputi bahan baku importasi pembelian jagung nasional, pembibitan, pabrik pakan, obat-obatan, budidaya, rumah potong ayam berikut cold storage, serta proses hasil unggas. Dapat dibayangkan kekuatan produksi para pemodal semua keperluan budidaya peternak sudah ada dalam agenda usahanya, karena berlakunya UU No 18/2009 ada pasal yang membolehkan perusahaan integrator melakukan usaha budidaya dan menjualnya di pasar tradisional (dalam

\footnotetext{
${ }^{1}$ Menurut KPPU, 2018. Kartel diartikan bentuk persekongkolan dari beberapa pihak yang bertujuan untuk mengendalikan harga dan distribusi suatu barang untuk kepentingan (keuntungan ) sendiri. Mopolistik adalah kondisi dimana hanya ada satu penjual yang menawarkan barang jasa di suatu pasar, termasuk juga dalam menentukan harga.
}

negeri) yang menjadi tumpuan pasar peternak rakyat.

Oleh karena itu ada usulan mengajukan uji materi pasal-pasal terkait pada UU No 18/2009 ke Mahkamah Konstitusi. Pengajuan ini dilakukan oleh Perhimpunan Dokter Hewan Indonesia (PDHI), Perhimpunan Peternak Sapi dan Kerbau Indonesia (PPSKI), Serikat Petani Indonesia (SPI), Wahana Masyarakat Tani Nelayan Indonesia (Wamti), Gabungan Koperasi SusuIndonesia (GKSI), dan Institute for Global Justice (IGJ). Pasal yang diuji Pasal 44 ayat (3), Pasal 59 ayat (2) dan (4), serta Pasal 68 ayat (4) UU No 18 Tahun 2009. Pasal-pasal tersebut telah melalaikan aspek keamanan konsumsi daging impor.Semangat pasal-pasal ini membuka impor daging sebesar-besarnya dengan mengabaikan keselamatan, dan mengabaikan atau tidak melindungi peternak kecil. Dampak impor daging dan dibenarkannya perusahaan besar sebagai integrator, yang mematikan usaha peternak kecil mandiri. Regulasi atau kebijakan tersebut menyebabkan terjadinya eksklusi sosial peternak, akses dan kesempatan usaha ternak sebagai hak warganegara tertutup.

Kedua, terjadi berbenturan dengan peraturan Pemerintah RI No.6 Tahun 2013 Tentang Pemberdayaan Peternak pada Bab I Ps 1 ; bahwa upaya pemberdayaan itu bertujuan agar peternak mandiri, mendapat kemudahan, kemajuan, daya saing dan sejahtera. Dalam pemberdayaan target akhirnya menjadi peternak mandiri dan sejahtera. Tentu harus diawali dengan adanya fasilitasi yang diberikan bagi peternak sehingga ada kemudahan akses untuk mendapatkan sapronak dan ada perlindungan dalam menentukan harga jual. Kondisi demikian akan menjadikan peternak berdaya saing dan berorientasi ekonomi atau maju. Kemudian mengenai prinsip kemitraan yang dikembangkan adalah adanya saling menguntungkan dan saling memperkuat antara usaha kecil dan usaha menengah atau besar (Ayat 5). Hal ini menunjukkan bahwa antara dua fihak tersebut diperlukan adanya kebijakan yang transparan dan terbuka dalam 
perhitungan hasil produksi dan faktor produksi dalam kegiatan usaha. Hal tersebut dapat dilakukan apabila ada kesediaan untuk merumuskan konvensi harga atau kesepakatan harga yang sudah dipertimbangkan oleh kedua belah fihak yang bermitra.

Ketiga, pada Pasal 3 poin I yang menegaskan perlu adanya perlindungan harga. Makna dari perlindungan harga ini adalah adanya konvensi dalam menentukan harga yang akan diterima oleh kedua fihak yang bermitra.

Keempat, adanya peran kelompok, dinyatakan dalam Bab II Ps 5 Ayat 2; yang menyatakan bahwa untuk mengakses permodalan akan diberikan melalui kelompok peternak atau gabungan kelompok peternak. Pada ayat ini dimaksudkan bahwa kelompok tersebut perlu ditegaskan bukan kelompok instan yang hanya muncul pada saat perlu dana tetapi harus sesuai dengan prinsip partisipatif sebagaimana dinyatakan dalam Ps29 Ayat 2. yaitu kelompok peternak dibentuk oleh, dari, dan untuk peternak.

Kelima, Prinsip kemitraan yang dinyatakan dalam BabV Ps 19 Ayat 2; bahwa kemitraan dapat dilakukan dalam bentuk bagi hasil, sewa, atau inti-plasma.Prinsip tersebut berkaitan dengan perkembangan pola kemitraan dimana bagi hasil merupakan basis dalam kegiatan bermitra yang dalam istilah lokal dapat berbentuk "maro".Sejalan dengan perkembangan dan tuntutan para peternak maka sistem bagi hasil klasik ini ditransformasikan ke dalam konsep baru yang disebut dengan kemitraan usaha inti-plasma.Makna dari mitra inti-plasma ini menunjukkan adanya perbedaan kelas pengusaha antara peternak kecil dengan peternak yang bermodal besar.Oleh karena itu dalam mekanisme pembagian keuntungannya perlu dirumuskan secara adil dan berprinsip berfihak pada peternak ekonomi lemah.

Inti dari peraturan pemerintah No 6 tahun 2013, mengarah kepada pengembangan peternak mandiri (Munandar, 2015) :
- Pemberdayaan peternakan yang menjadikan usaha peternakan mandiri.

- Adanya perlindungan harga

- Kedua hal tersebut saling berkaitan karena, kemandirian usaha diperlukan agar peternak dapat melakukan usahanya secara berkelanjutan. Hal tersebut dapat terjadi apabila ada perlindungan harga, tidak mengalami fluktuasi harga, yang dapat merugikan peternak.

Upaya pemerintah dilakukan melalui Peraturan Menteri Pertanian Nomor 26/2016 tentang Penyediaan, Peredaran dan Pengawasan Ayam Ras, mengeluarkan harga patokan ayam ras pedaging.Dalam praktiknya ternyata tidak dapat mengontrol harga, hal ini sebagai terganggu kelembagaan dan partisipasi peternak rakyat.

Berbagai dampak eksklusi sosial peternak tampak adanya kebijakan kontra produktif yang dilahirkan bias dan kurang mendukung terciptanya kemandirian pangan nasional. Pada kasus komoditi daging sapi, kebijakan yang muncul sering kali menjadi kontra produktif dan bahkan menimbulkan kekhawatiran para pihak bahwa kebijakan tersebut secara jangka panjang bisa mengancam kemandirian pangan khususnya pembangunan peternakan rakyat sebagai sumber pangan asal daging sapi nasional.Misalnya, perubahan kebijakan produksi menjadi pendekatan harga (Permendag 669/2013), rasio impor sapi bakalan dan sapi indukan (Permentan No. 49/2016), impor daging kerbau yang berasal dari India (SK Mentan No. 2556/2016), impor daging sapi tanpa kuota serta diubahnya kebijakan Impor sapi bakalan, dari berat 350 $\mathrm{kg} /$ ekor menjadi $450 \mathrm{~kg} /$ ekor. Demikian juga "Jebakan pangan daging sapi", mengandung pengertian ketidakmampuan sarana dan prasarana produksi pangan asal ternak sapi di dalam negeri untuk bersaing dengan daging sapi import, dengan kata lain, lemahnya daya saing produksi daging sapi di dalam negeri. Pola dasar kebijakan "harga murah" bukannya "harga 
terjangkau" merupakan awal dari bencana jebakan pangan daging sapi. Ketidakmampuan bersaing dengan harga yang murah ini telah menyebabkan pemerintah mengambil kebijakan jalan pintas; yaitu memilih "komoditi daging import" ketimbang bersusahpayah "berbudidaya dan berproduksi" di dalam negeri, yang diusahakan peternak yang dibangun berbasis pada keragaman sumberdaya bahan baku pangan, kelembagaan dan budaya lokal. (Tawaf, 2017). Realitas sekarang semakin tidak efisiennya sistem produksi daging sapi/kerbau di dalam negeri. Fenomena tersebut tampak gamblang berdasarkan data BPS (2013) yang diolah Gapuspindo (2016) dan Bapenas (2015), bahwa diprediksi rasio kemampuan produksi domestik dengan impor makin mengecil yaitu dari $73 \%$ ditahun 2011, menjadi sekitar 65,4\% (2015) dan $56,1 \%$ di tahun 2019. Dari data tersebut, telah terjadi defisit tumbuh produksi domestik dengan impor, sekitar $13,47 \%$ sedangkan impor daging dan sapi tumbuh positip sebesar $4,33 \%$. Artinya, ketergantungan terhadap impor semakin meningkat, yang akan dirasakan di DKI Jakarta dan Jawa Barat.

Peternakan rakyat yang semula sebagai pilar ketahanan pangan pada masyarakat desa juga mengalami nasib yang tidak menentu. Akibat eksklusi sosial kepentingan pemodal besar berimbas pada regulasi yang memarjinalkan peternakan rakyat.Sejak nomenklatur peternakan rakyat tidak lagi tercantum dalam UU No. 18/2009 tentang peternakan dan kesehatan hewan, nasib dan masa depan peternakan rakyat kian suram. Semula lebih dari $90 \%$ usaha peternakan sapi dan kerbau; unggas lokal dan domba/kambing dikuasai oleh peternak rakyat. Namun sekarang mengalami penurunan. Penurun drastis pada usaha peternakan ayam ras. Menurut Pataka (2016) dalam sepuluh tahun terakhir bisnis usaha peternakan ayam ras kian lesu, pada tahun 2006 peternakan rakyat menguasai $70 \%$ pangsa pasar unggas nasional. Namun, pada tahun 2016, porsi peternakan rakyat tinggal $18 \%$.
Tidak sedikit usaha peternak skala Usaha Mikro Kecil dan Menengah (UMKM) juga bangkrut (Tawaf, 2016).

Fenomena yang terjadi pada kasus marjinalisasi peternakan rakyat karena pengertian peternakan rakyat lebih ditekankan kepada bentuk usaha UMKM.Sesungguhnya, peternakan rakyat adalah kegiatan usaha ternak yang dilakukan WNI baik skala UMKM maupun Korporasi. Usaha ini harus menjadi kuat dan tangguh,yang menguasai pangsa pasar di rumahnya sendiri bukan sebaliknya, mereka harus dibina dan dibesarkan bukannya dikerdilkan.

Berbagai kebijakan yang kontroversi pemerintah yang kontra produktif dalam membangun peternakan (sapi potong) sebagai berikut :

- Larangan penggunaan hormon pertumbuhan pada usahaternak sapi potong tertera dalam UU 41/2014 pasal 22, ayat 4C. kebijakan ini tidak konsisten dengan realitanya, yaitu melakukan importasi daging dan sapi dari negera-negara yang menggunakan hormon pertumbuhan. Seharusnya peternak di dalam negeri diperbolehkan menggunakan hormon pertumbuhan sesuai dengan persyaratan yang berlaku.

- Kebijakan yang menyangkut lama pemeliharaan penggemukan sapi potong minimal 120 hari, (lihat UU 41/2014 tentang PKH, pasal 36B, ayat 5). Padahal usaha penggemukan, dikenal dengan konsep "pertumbuhan kompensasi", yaitu memanfaatkan waktu yang tercepat untuk menghasilkan pertambahan berat badan yang paling optimal, bukan diukur dengan lamanya waktu (minimal 120 hari).

- Kebijakan mengenai perubahan pendekatan pembangunan dari produksi kepada harga daging sapi (lihat Permendag 699/2013). yaitu penetapan harga daging sapi Rp. 80 ribu/kg yang hingga kini belum terwujud, 
telah melahirkan kebijakan impor daging yang tanpa kendali.

- Kebijakan perubahan berat badan pada impor sapi bakalan dari $350 \mathrm{~kg}$ menjadi 450 kg (Permentan 49/ 2016 ke 02/ 2017 pasal 15), bila digemukan 120 hari, tidak ada peluang pasar bagi peternak penggemukan, karena selera konsumen berat 400-500 kg.

- Kebijakan membebaskan impor daging dan sapi (lihat Permentan No 17/2016, 34/2016 dan permendag 59/2016). Kebijakan ini sesungguhnya bisa dilakukan, jika untuk memenuhi kebutuhan konsumen serta merangsang produksi ternak di dalam negeri.

- Kebijakan membuka impor dari negara yang belum bebas Penyakit Mulut Kuku PMK) (lihat PP 4/2016 dan SK Mentan No.2556/2016). Kebijakan ini jelas-jelas bertentangan dengan UU No.41/2014 tentang PKH pasal $36 \mathrm{E}$ ayat 1 , yang akan terjadinya outbreak PMK yang sangat membahayakan.

- Kebijakan rasio impor sapi bakalan dengan indukan (lihat Permentan 02/2017 pasal 7). Kebijakan ini akan di evaluasi pada akhir tahun 2018, yang akan mematikan bisnis penggemukan, pengurasan populasi sapi lokal dan sapi perah serta meningkatnya pemotongan sapi betina produktif serta penurunan produktivitas usaha tani di perdesaan.

Hal demikian sebagai bentuk eksklusi sosial pada bidang sapi potong, sehingga tampak bahwa eksklusi sosial tejadi pada ternak unggas dan ternak sapi potong.

\section{Dampak Eksklusi Sosial}

Respon masyarakat peternak akibat eksklusi sosial melalui regulasi yang tidak memihak kepada peternak, melakukan Kongres Nasional Peternakan rakyat yang diselenggarakan tanggal 28 November.2016 di Jakarta, merupakan salah satu bentuk adanya disintegrsi dalam eksklusi sosial dan sebagai upaya menampilkan jatidiri peternakan rakyat sebagai akibat iklim usaha, kebijakan pemerintah dan perundangan yang tidak kondusif dan mengeksklusi sosial peternak sehingga peternak tidak memiliki akses terhadap sumber daya peternakan. Hasil kongres dirumuskan : Tanggal 28 November sebagai hari peternakan nasional; terbentuk Dewan Peternakan Nasional (DEPERNAS); Secara ringkas rumusan hasil kongres:

- Pemerintah harus memperhatikan keberadaan peternak rakyat; Pemerintah segera mencabut UU.No.18 thn 2009 tentang peternakan dan kesehatan hewan Jo.UUNo.41/2014 tentang perubahan atas UU no 18/2009.

- Pemerintah segera menghentikan impor ternak atau produk ternak dari negara yang belum bebas penyakit mulut dan kuku.;

- Pemerintah segera menghentiakn impor ternak yang sebenarnya mampu diproduksi peternak rakyat; Pemerintah segera memanfaatkan secara maksimal sumber daya genetik ternak asli Indonesia (www.pataka.or.id.; Suara Akar Rumput Tani Indonesia (ARTI). Ed II Nop-Des.2016).

Hasil kongres peternak rakyat ini merupakan antiklimaks perjuangan untuk membongkar segala kemelut dan blokade akibat eksklusi sosial peternak yang diakibatkan oleh berbagai regulasi yang dijalankan pemerintah yang tidak memihak peternak rakyat. Hal ini senada dengan Sullivan (2002) bahwa ketika identitas individu seseorang atau identitas kolektif suatu kelompok atau komunitas (peternak) mengalami ancaman dalam relasinya dengan kelompok tertentu atau kategori sosial tertentu (pemodal besar), maka individu atau kelompok (dalam hal ini peternak) memilih sebuah strategi untuk mengatasi eksklusi sosial tersebut lewat sebuah keanggotaan pada sebuah kelompok alternatif atau kategori sosial tertentu (peternak rakyat) yang dapat memberikan masukan atau feed back positif untuk terus menjaga sebuah identitas (peternak rakyat) yang sifatnya positif. 


\section{Ekses Eksklusi Sosial:}

Akibat eksklusi sosial yang tercatat dari berbagai media formasi (2015-2019) menimbulkan ekses sebagai berikut:

- Harga Jual Ayam Hidup dibawah HPP (Sumber Media Sosial/lihat di daftar pustaka) Terjadinya harga jual ayam hidup dibawah harga produksi pokok, datanya menunjukkan bahwa a harga ayam hidup Rp.8000/kg. padahal HPP Rp. 18.000/kg. Kasus ini menyebabkan peternak mandiri rugi 1,7 trilyun dengan harga Rp.12.000/kg dan memproduksi 18 juta ekor/minggu. Hal ini terjadi karena ekspansi berlebih breeder setelah unggas untung tahun 2010-2012. Praktek monopoli semula DOC 554 ribu naik $62 \%$ sehigga tahun 2015 menjadi 64 juta ekor/minggu. Padahal kontribusi ternak dalam ekonomi nasional menyerap 2,5 juta tenaga kerja langsung dengan omset 120 trilyun.

- Muncul Gerakan Protes.

Gerakan protes peternak muncul dengan membagikan ayam yang over suplply, dilakukan oleh perhimpunan peternak Insan Rakyat Semarang Jateng pada tgl 26/6/2019, mereka mengalami kerugian 240 juta-10 milyar, karena harga jual ayam hidup hanya 8-9 ribu /kg. Kemudian Paguyuban Peternak Mandiri protes karena harga ayam hidup (livebird) dibawah harga pokok produksi (HPP). Aksi mereka membagikan ayam se jawa dilakukan oleh GOPAN/gabungan organisasi peternak ayam nasional pada $5 / 9 / 19$.

- Muncul Rekomendasi dari Organisasi Peternakan

Sejumlah kalangan menuding, situasi ini dipicu oleh Undang-Undang (UU) No 18/2009 tentang Peternakan dan Kesehatan Hewan.Maklum, UU ini membuka peluang industri masuk secara leluasa di bisnis budidaya. Pengaturan suplai indukan juga tidak dibuat yang mengakibatkan fluktuasi harga ayam.Ketua Pusat Kajian Pertanian Pangan dan Advokasi (Pataka) Yeka Fatika berdasarkan penelitian yang dilakukan di dua kabupaten di Jawa Barat, yakni di Karawang dan Bogor, bahwa peternak mandiri menderita kerugian besar."Potensi kerugian yang dialami peternak di dua kabupaten ini saja mencapai antara Rp 746 miliar hingga Rp 1,49 triliun per tahun," ujarnya, Kamis (3/11/2016). Marginalisasi peternak unggas mandiri terjadi dalam tiga pola. Pertama, marginalisasi usaha, terjadi ketika peternak bangkrut.;Kedua, marginalisasi skala usaha, terjadi pada saat peternak mengalami penurunan skala usaha. ;Ketiga, marginalisasi kemandirian terjadi pada saat peternak berubah dari peternak mandiri menjadi peternak plasma. Dalam lima tahun terakhir, telah terjadi penurunan skala usaha peternak UMKM dari 35.000 DOC per minggu menjadi 17.000 DOC per minggu.Ini berdampak terhadap pengurangan jumlah peternak UMKM dan meningkatnya peternak plasma.

- Masukan dari Ikatan Sarjana Peternakan: Kebijakan pembangunan peternakan menimbulkan kontra produkstif, hal ini dibuktikan dari hasil FGD (15 JUNI 2015) Ternyata : Kelebihan pasokan ayam; feedmil dihasilkan 18,5 juta ton padahal kebutuhan 13 juta ton; DOC pertumbuhan $20 \%$ padahal permintaan kurang dari $15 \%$ sehingga over produksi. Hal ini tidak sesuai dengan target tujuan bisnis ayam (Balitbang Kementan) yaitu membangun kecerdasan dan menciptakan kesehatan masyarakat; meningkatkan pendapatan peternak dengan skala usaha; meningkatkan lapangan kerja; kontribusi pendapatan devisa. Peran pemerintah adalah: melindungi; mencegah persaingan;mencegah peny menular; dukung infra struktur.Saran dari ISPI yaitu kendalikan impor GPS; Hentikan liberalisme usaha 
sesuai UU No. 18/2009 dan UU No.6 1967. Kondisi yang terjadi menurut PB.ISPI Peternak .rakyat rontok karena dihisap perusahaan asing. Menurut PPUI daya saing peternak mandiri lemah karena adanya integrasi dan tambah lagi pasar bebas ASEAN. ISPI menyarankan agar cabut UU No.18/2009 kembalikan ke UU No.6 1967. Kemelut peternakan sampai tahun 2019 harga jual ternak di kandang renda dibawah biara pokok dan sistem kartel masih berjalan yaitu: Mekanisme pasar; Kebijakan pemerintah; mengerucut hanya perusahaan tetrtentu yg usaha Perusahaan mengelompok menciptakan ketemtuan sendiri monopoli ; Pemerintah yg tanggungjawab seperti daging sapi beban sektor pertanian. Pernyataan dari gabungan PINSAR/perhimpunan insan perunggasan rakyat; GOPAN/gabungan organisasi peternak ayam nasional; PPUN/perhimpunan peternak unggas nusantara (5/3/2019): bahwa peternak mandiri dimarjinalkan atau dikerdilkan yaitu: a. persaingan tidak sehat karena budidaya diserahkan kepada pengusaha besar seperti dalam UU Peternakan no $18 / 2009$ psl 29 ayat 1. : Budidaya ternak hanya dapat dilakukan peternak, perusahaan peternakan, serta pihak tertentu untuk kepentingan khusus; b. peternakan mandiri dan perusahaan berebut dalam pasar sama tradisional dengan pangsa pasar $80 \%$; c. pemerintah tidak mau mengatur pasokan dan distribusi DOC yg mempengaruhi pasokan ayam hidup; d. harga DOC dan pakan meningkat.

\section{b. Pemberdayaan Rekonstruksi Komprehensif}

Berdasarkan kajian fenomenologi, studi dokumen dan studi kasus, ditemukan permasalah krusial yang menyebabkan peternak tereksklusi sosial, peternak rakyat mandiri bangkrut, dengan gejala umum harga produksi (ayam hidup) dibawah harga biaya produksi yang terus secara periodik terjadi; Gulung tikarnya peternak mandiri; Semakin lemah posisi tawar peternak mandiri; Perusahaan besar merebut pasar tradisional dan ; Monopoli pemasaran DOC. Maka konsep pemberdayaannya adalah merekonstruksi regulasi dan menyusun model kebijakan yang partisipatif atau hasil konvensi. Pemberdayaan (empowerment) dalam hal ini adalaha proses memberikan daya atau kekuatan; Transfer kekuasaan melalui penguatan modal sosial (trust, role, networking) untuk menjadi produktif ; pemenuhan kebut dasar, akses sumber produktif; partisipatif (Suharto,2005); juga upaya pembebasan; transformasi struktural secara fundamental dan eliminasi struktural (Ife, 1996.59). Pemberdayaan yang sifat struktural komprehensif sebagai berikut:

\section{Merekosntruksi Peternakan \\ Rakyat/Mandiri Sebagai Basis Ekonomi}

Konsep regulasi, yang dilakukan dengan memberdayakan peternak sebagai basis ekonomi usaha ternak. Hal ini demikian dilakukan dengan asumsi apabila peternak rakyat menjadi basis ekonomi maka regulasi dengan sendirinya akan menopang peternak rakyat. Dalam suatu masyarakat (peternak) ada sistem ekonomi dasar (ekonomi base) sebagai substruktur dari masyarakat yang memiliki cara produksi, kekuatan produksi dan relasi akibat produksi, yang diartikan sebagai hubungan sosial yang ditemukan dalam produksi. ${ }^{2}$ Masyarakat peternak khusus peternak sapi potong dan unggas/ayam sebagai produksi atau reproduksinya (basis ekonominya) ada di pengusaha feedloter, pengusaha integrator minus peternak rakyat atau peternak mandiri, artinya kelompok tersebut sebagai pemodal kuat dan peternak rakyat/mandiri hanya sebagai bagian, subordinasi atau tereksploitasi. Hal demikian dengan sendirinya akan mempunyai kekuatan dalam relasi sosial akibat produksi, yang akan dibangunnya dalam superstruktur masyarakat

\footnotetext{
${ }^{2}$ Cupp and Payne. 1980. Perspective in Sociology. George Allen \& Unwin London. Hal 67-70
} 
peternak berupa ekonomi politik seperti regulasi yang sesuai kepentingannya kelompok ekonomi base. Ekonomi basis akan membangun struktur berupa hubungan social akibat produksi, aktor yang ada di struktur ini peternak rakyat, konsumen dan pedagang pasar, pedagang besar, distributor, bandar dan poultry shop, termasuk regulator (Gambar 1).

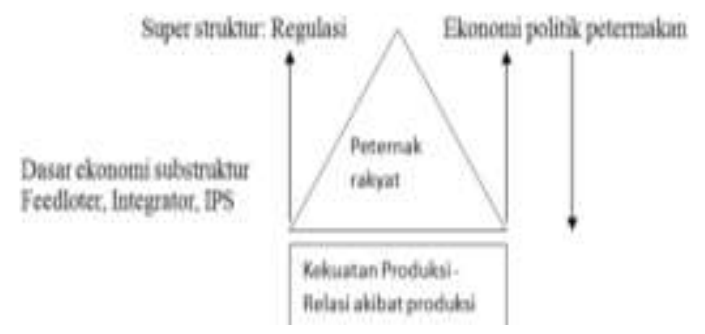

Gambar 1.

Rekonstruksi Peternakan Rakyat/Mandiri Sebagai Basis Ekonomi

Kesemua pelaku/aktor tersebut akan mengalami dampak kekuatan produksi atau reproduksi (social relation of production) berupa nilai kurang (minus value), sebaliknya para peternak ekonomi basis/pemodal besar akan mendapatkan nilai lebih (surplus value), bahkan ada yang teralienasi, seperti pada kasus peternak ayam mandiri yang banyak gulung tikar. Kemudian implikasi dari kekuatan struktur tersebut akan terefleksi pada superstruktur berupa ide, ideologi, regulasi atau norma yang berpihak kepada peternakan ekonomi basis (para pengusaha pemodal besar).

Kesemua pelaku/ aktor tersebut akan mengalami dampak kekuatan produksi atau reproduksi (social relation of production) berupa nilai kurang (minus value), sebaliknya para peternak ekonomi basis/pemodal besar akan mendapatkan nilai lebih (surplus value), bahkan ada yang teralienasi, seperti pada kasus peternak ayam mandiri yang banyak gulung tikar. Kemudian implikasi dari kekuatan struktur tersebut akan terefleksi pada superstruktur berupa ide, ideologi, regulasi atau norma yang berpihak kepada peternakan ekonomi basis (para pengusaha pemodal besar).

\section{Kebijakan Partisivatif atau Konvensi Harga}

Secara fenomenologis realitas yang dialami, bukan realitas yang sebenarnya, karena kesadaran tertutup realitas, realitas perlu dikonstitusikan, karena mengandung profilprofil, melalui tindakan kesadaran, akan menemukan hal sebenarnya ${ }^{3}$ Profil-profil dalam basis ekonomi peternakan adalah pengusaha feedloter, integrator, (Industri Pengolah Produksi Susu) yang menutupi realitas, sehingga perlu dikonstitusikan, dicairkan, bagaimana korelasi harga dengan fropil profil tersebut.

Kestabilan ekonomi dan sosial dari hulu sampai hilir terjadi apabila harga pasar (sebagai norma) yang umum (kesepakatan) mengatur perilaku ekonomi pelaku kelembagaan daging, persusuan; Pada kondisi anomali atau inflasi maka harga pasar kehilangan fungsi pengaturannya. Atas dasar tesis demikian maka restrukturasi kelembagaan daging, persusuan diperlukan adanya "konvensi norma (harga)" mengenai input dan output diantara para pelaku kelembagaan. Untuk mencapai konvensi harga riil silahkan perhitungkan secara ekonomis sebagai dasar penetapannya yang dijastifikasi secara sosial (diterima semua pihak) yang dikawal regulator. Artinya ada konvensi bakal keutungan yang akan diterima, dengan pertimbangan indikatornya ingin mensejahterakan semua fihak/aktor khususnya peternak rakyat untuk kondisi sekarang. Fenomena protes dilakukan pedagang pasar dengan berhenti berjualan.

\section{Pemberdayaan Pola Kemitraan}

Fenomena lain adalah gulung tikarnya peternak ayam rakyat/mandiri yang tersisa 20 $\%,{ }^{4}$ yang merupakan akibat dari kondisi

\footnotetext{
${ }^{3}$ Perdue D. William. Loc.cit..

${ }^{4}$ Litbang Kompas 4 Maret, www.kppu.go.id.;

www.antarnews.com.
} 
kelembagaan peternakan berupa aturan atau norma pola kemitraan yang sekarang berlangsung. Untuk analisis ini diperlukan pendekatan teori pertukaran (exchange theory) dari Homans. ${ }^{5}$ Pola kemitraan adalah pertukaran/kerjasama antara inti/plasma/ pemodal/pabrikan dengan peternak/ plasma. Pada pertukaran ini berlaku proposisi a. Proposisi Sukses : Untuk semua tindakan yang dilakukan seseorang; Semakin sering tindakan khusus seseorang diberi keuntungan/hadiah, semakin besar kemungkinan orang melakukan tindakan itu.

Hasil penelitian menunjukkan semakin berkuran peserta kemitraan unggas/ayam yang beralih ke maklun, bahkan maklun juga pikir pikir dulu karena sering mengalami kerugian. Protes peternak pola maklun ditolak kalau jatah memeliharanya sedikit, karena upahnya per ekor, kalau memelihara jumlah banyak, upah pun akan besar. Poultry shop mengurangi jatah karena pemasaran dan harga sapronak tidak kondusif. $^{6}$ Peternak malas untuk mengulang lagi kerjasama kemitraan, hanya yang punya modal besar yang berani bermitra. Fenomena sebagai akibat kuatnya tekanan para pemodal yang menyebabkan posisi tawar peternak termarjinal menyebabkan timbulnya penyimpangan perilaku sosial peternak, berupa berani melanggar peraturan memotong sapi betina produkstif dan memotong sapi perah untuk dijadikan ternak pedaging, karena tergiur harga daging yang tinggi serta kondisi keuntungan peternak yang minim. Demikian pula terjadi penyimpangan memalsukan air susu dengan menambah air beras. ${ }^{7}$

\section{Pemberdayaan Penguatan Usaha Ekonomi (Sumber Pendapatan)}

Fenomena protes/demo para pelaku usaha ternak, menunjukkan adanya perbedaan kepentingan yang dapat menimbulkan konflik. Kontradiksi

\footnotetext{
${ }^{5}$ Turner H. JonathanThe Structur of Sociological Theory. Wadsworth Publishing Co. California. Hal. 303-327.

${ }^{6}$ Munandar; Firdaus. Siti Homzah. Loc.cit.

${ }^{7}$ Munandar , Tasripin, Homzah. 19...
}

terjadi antara pedagang pasar dengan distributor; peternak plasma dengan inti/pengusaha; feedloter dengan pemerintah. Melalui adaptasi analisis Paige (1970), konflik terjadi akibat perilaku ekonomi politik berbeda, dimana perilaku ekonomi politik tersebut dipengaruhi sumber penghasilan yang berbeda. Ada penghasilan dari sapi bakalan; sapronak (integrator), disatu pihak dan dilain pihak dari upah (penggemukan; maklun; jual produk). Ilustrasinya berikut ${ }^{8}$ :

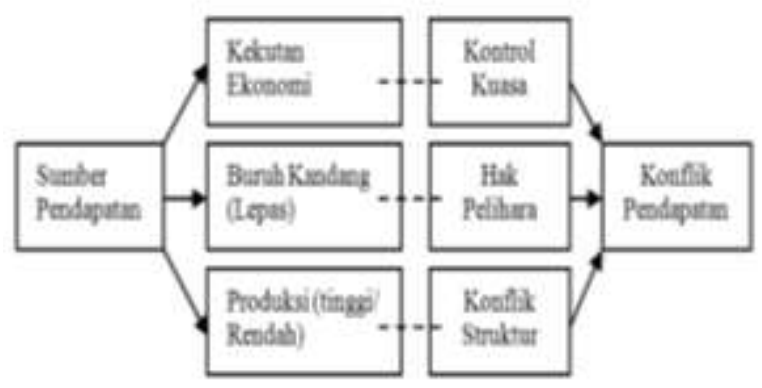

Gambar 2. Pemberdayaan Penguatan Usaha Ekonomi

Kekuatan ekonomi (pengusaha modal besar) akan berkuasa mengontrol faktor produksi,buruh kandang punya hak memelihara dan sifat produksi tinggi/rendah menimbulkan konflik struktur (monopsoni, oligopoli) yang berakibat konflik menyangkut/fokus pendapatan, pendapatan terganggu.

Terbukti melalui analisis ekonomi politik, bahwa ekonomi basis menentukan harga (norma), meskipun ada intervensi pemerintah. Demikian pula pengusaha pabrikan atau integrator pada pola kemitraan menyebabkan posisi tawar peternak sangat lemah, dibuktikan beralihnya peternak ke pola maklun. Dalam hal ini pemerintah melalui regulasinya merupakan kekuatan bersama dengan para pelaku usaha (ekonomi basis) untuk menstabilkan usaha. Pembangunan berkelanjutan berjalan dengan: penciptaan mekanisme partisipatif dan posisi tawar seimbang berbasis modal sosial (jujur,

\footnotetext{
${ }^{8}$ Jeffry M.Paige, Agrarian Revolution: Social movement and export agrarian in under developed world. N.Y.Free Press.1970.hal 22.
} 
kerjasama dan jaringan sosial) (Colleman, 2000). Kondisi partisipatif dan posisi tawar seimbang akan dicapai apabila ada sinergi dalam Kebijakan/tupoksi (regulator, kebijakan) program, kelembagaaan (operator, pelaku usaha) dan peternak (stakeholder) serta tidak ada kepentingan politik, seperti alur mekanisme berikut:

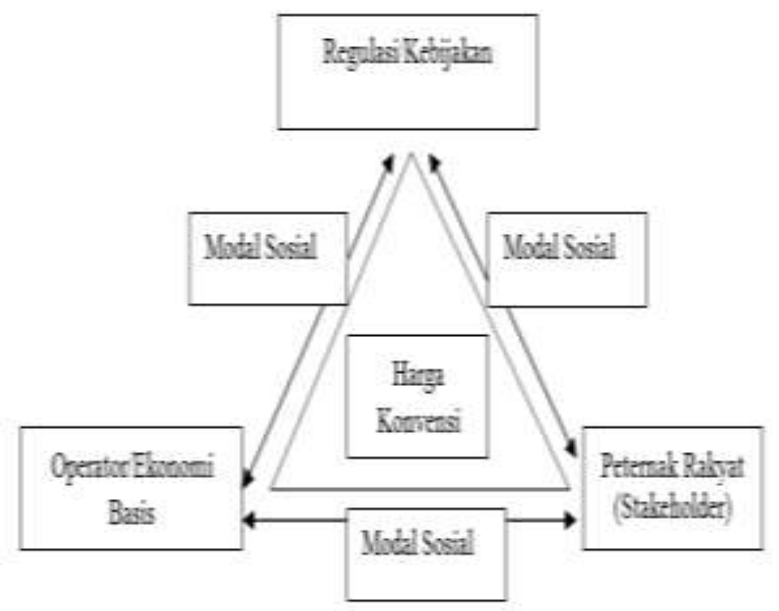

Gambar 3. Kondisi Partisipatif Dan Posisi Tawar Seimbang

Mekanisme kerja sinergitas produksi antar regulator, operator dan peternak rakyat : Regulator, pemerintah dengan segala peraturannya merupakan suatu peraturan yang dapat dilaksanakan sesuai kemampuan operator dan terlindungi peternak rakyat; Demikian pula operator melakukan sesuatu yang sesuai peraturan dan undang undang (tidak monopoli tidak monopsoni, kartel, integrator) yang akan membebani peternak rakyat, tetapi membantu menyelesaikan masalah petani ; Peternak rakyat mampu melaksanakan regulasi dan mampu menjalankan kerjasama/bermitra dengan operator. Unsur modal yang merupakan potensi terdiri kejujuran, kepercayaan, kerjasama, tanggungjawab, menyelesaikan masalah bersama, norma dan nilai, ${ }^{9}$ diperlukan untuk pengikat dan pembangunan jaringan serta mengontrol komitmen.

\footnotetext{
${ }^{9}$ Colleman, James S. 2000. Social Capital in The Creation of
} Capital in The Creation of Human Capital.
Dari fenomena permasalahan peternakan berupa : kebijakan sepihak, system kartel ${ }^{10}$, didikte bandar dan dominasi pemodal. Semuanya merupakan variable sosial tentang kelembagaan, yang perlu direkonstruksi secara ketat sehingga merupakan system pembangunan berkelanjutan. Kemitraan sebagai mekanisme pembangunan perlu mempunyai visi bahwa hasilnya dalam rangka mensejahterakan peternak dan bebas dari garis kemiskinan. Jadi yang perlu dikembangkan adalah jasa sosial yang ditanam dalam proses produksi harus menjadi ukuran dan mendapat penghargaan, bukan jasa besarnya finansialnya saja yang ditanam dalam suatu usha ternak kemitraan. Karena walaupun bagaimana peternak kecil itu tidak punya modal dan usahanya dapat berjalan kalau didongkrak dengan modal besar.

\section{KESIMPULAN}

\section{a. Kesimpulan}

1. Eksklusi sosial muncul karena berkaitan dengan akar masalah adanya regulasi peternakan yang sifatnya integrasi yaitu UU Peternakan no 18/2009 psl 29 ayat $1 .:$ Budidaya ternak hanya dapat dilakukan peternak, perusahaan peternakan, serta pihak tertentu untuk kepentingan khusus.

2. Pemberdayaan bagi peternak rakyat mandiri yang tereksklusi sosial dilakukan secra rekonstruksi komprehensif dan sinergi yaitu rekonstruksi usaha ternak sebagai basis ekonomi, kebijakan konvensi harga, pola kemitraan proposisi sukses dan penguatan usaha ekonomi

\section{DAFTAR PUSTAKA}

Byrne.1999, dalam Haralambos and Holborn. 2004. Sociology Themes and Perspectives. Harper Collins Publisher Ltd.London

\footnotetext{
${ }^{10}$ Sistem kartel adalah kelompok produsen indevenden yang bertujuan menetapkan harga, untuk membatasi supli dan kompetisi, yang selalu ada baik di ranah nasional maupun internasioanl (Hukum monopoli, kartel dilarang) (http://id.m.wikipedia..org..wiki. Kartel. 11/09/016)
} 
Munandar dkk.. 2015. Pola Kemitraan Unggas Jawa Barat. Kerjasama Dinas Peternakan Provinsi Jawa Barat Bandung.

Munandar dan Rochadi,.2018. Peran Peternakan dalam SDGs dan Tantangan Eksklusi Sosial. Dalam Buku. Agrokompleks Menjawab Tantangan SDGs. Pemikiran Para Profesor (Edit. Sutyastie Soemitro Remi.dkk). Dewan Profesor Senat Akademik Unpad Press. Hal.33-51.

Ife. Jim, 2005. Tesoriero Community Development. Penerbit Pustaka Pelajar Yogya

Robert W. Kates, Thomas M. Parris, dan Anthony A. Leiserowitz, "What is Sustainable Development? Goals, Indicators, Values, and Practice." http://www.un.org/sustainabledevelopment

Suharto .2005.Membangun masyarakat memberdayakan masyarakat. Refika Aditama Bandung.

Sen. Amartya. 2000. Social Exclusion and Social Solidarity: Three Paradigms. Manila: Office of Environtment and Social Development. Asia Development Bank. Hal.15

Sullivan, 2002. Social Exclusion, Social Identity and Social Capital: Reuniting The Global, www.eephemeraweb.org/ journal/5-2/5-2 index.htm

Susan Baker, Maria Kousis, Dirk Richardson, and Stephen Young, ed., The Politics of Sustainable Development: Theory, Policy, and Practice within the European Union, (London: Routledge, 1997), hlm.57. http://www.un.org/sustainabledevelopment/

Smith, Jonathan A. Flower, Paul, Larkin, Michael, 2009. Interpretative Phenomenological analysis: Theory, method and Research. Washington Sage.

Suara Akar Rumput Tani Indonesia (ARTI). Ed II Nop-Des2016). www.pataka.or.id.

Tawaf, R . 2017. Kumpulan Artikel Peternakan. Dept, Sosek Fapet Peternakan Unpad.

Todman, Lynn C., 2004. Reflections on Social Exclusion: What is it? How is it differens U.S Conceptualization of disadvantage?. Bicocca Italia Dept. of Sociology and Social Research Univ. of Milan.

Permasalahan dan Berita Peternakan:

http//bisnis.com/smg:

https://m.republika.co.id 28/11/018 ;

www.troboslivestock.com; http.tribun.com; https://regional.kompas.com; www.tribunnews.com/bisnis/2016/. www.pataka.or.id. 